\title{
Cikkismertetés: Az önbizalom és a nem hatása a stresszreakciókra
}

\author{
Article review: Impact of self-esteem and sex on stress reactions
}

Ismertető: $\quad$ Varga Szabolcs $\square$

Debreceni Egyetem Népegészségügyi Kar, Megelöző Orvostani Intézet

Ismertetett cikk: Kogler L, Seidel EM, Metzler H, Thaler H, Boubela RN, Pruessner JC, Kryspin-Exner I, Gur RC, Windischberger C, Moser E, Habel U, Derntl B. Impact of self-esteem and sex on stress reactions. Sci Rep. 2017;7(1):17210. doi: 10.1038/s41598-017-17485-w

Beküldve: $\quad$ 2019. 05. 24.

doi: $\quad$ 10.24365/ef.v60i5.471

Kulcsszavak: stresszreakciók; dohányzás; alkoholfogyasztás; nem; önbizalom

Keywords: stress reactions; smoking; drinking; sex; self-esteem

A pozitív önértékelés és énkép az egyik fő pszichológiai tényező, mely befolyásolja az egyén stresszkezelési magatartását. A témával foglalkozó kutatások már felhívták a figyelmet a nemi különbségekre mind az önértékelésben, mind a stresszkezelésben, azonban a két változó egyidejú hatását még nem vizsgálták.

Egy nemzetközi munkacsoport az önértékelés és a stresszkezelés kapcsolatát, valamint annak nemi különbségeit vizsgálták hormonális, viselkedési és idegi szinten egyaránt. A kutatók 80 egészséges résztvevőt vontak be a mintába, akik funkcionális mágnesesrezonancia-vizsgálat (fMRI) alatt kapott, stresszt kiváltó feladatokat végeztek el.

A férfiaknál stresszhatás közben a nőkhöz képest nagyobb aktivitást mértek az agy bizonyos területein: hippocampus, STG és insula. A férfiak teljesítménye a nőkkel összevetve jobb volt stresszhatás alatt, és az átlagos kortizol- és tesztoszteron- szintjük is magasabb volt a stresszhatás utáni szakaszban. A férfiak a nőkhöz képest erősebben vesznek igénybe olyan agyi területeket, amelyek az érzelmeket, a stresszkezelést, az önértékelést és a tudatos reakciókat szabályozzák.

A megfigyelt változások igazolták, hogy az önbizalom hatással van a stresszkezelés folyamatára, és ez a hatás nemektől független. Az alacsonyabb önbizalommal rendelkező résztvevők esetében azon agyi területek mutattak nagyobb aktivitást, melyek az érzelmi és stressz-szabályozásért és a kognitív kontrollért felelősek.

A kutatók másik következtetése az volt, hogy a férfiak a nőknél több erőforrást mozgósítanak a streszszel járó feladatok teljesítéséhez. Az alacsony önbizalom mindkét nem esetében növelte az érzelmek és a stressz feldolgozására, tudatos legyőzésére fordított erőfeszítéseket.

\section{TANULSÁGOK A HAZAI SZAKEMBEREK SZÁMÁRA}

A dohányzás és az alkoholfogyasztás egyik fő motivációs tényezője a stresszhatásokkal való megküzdés. Sokan használják ezen káros szenvedélyek hatásait arra, hogy stresszhelyzetek után megnyugodjanak, belső feszültségüket csökkentsék. ${ }^{1}$ 
Az ismertetett kutatás rávilágít arra, hogy az alacsony önbizalommal rendelkező egyének nagyobb erőfeszítést tesznek a stresszhelyzetek belső szabályozására, hajlamosabbak a stressz elfojtására, így körükben nagyobb teret kaphatnak a káros szenvedélyek, mint más lehetséges megküzdési mechanizmusok. A kutatás konklúziója megfelel és egyik magyarázatául is szolgál azoknak a nemzetközi eredményeknek, melyek az alacsony önértékelés és a káros szenvedélyek kapcsolatát mutatták ki. ${ }^{2,3,4}$

\section{TÁMOGATÁS}

A közlemény a Tempus Közalapítvány támogatásával készült.

\section{RÖVIDITÉSEK}

STG - Superior temporal gyrus

\footnotetext{
${ }^{1}$ Piko BF, Varga S, Wills TA. A Study of Motives for Tobacco and Alcohol Use Among High School Students in Hungary. J Community Health. 2015;40(4):744-9. https://doi.org/10.1007/s10900-015-9993-4

${ }^{2}$ Taremian F, Yaghubi H' Pairavi H, Hosseini SR, Zafar M, Moloodi R. Risk and protective factors for substance use among Iranian university students: a national study. Subst Abuse Treat Prev Policy. 2018;13(1):46.

https://doi.org/10.1186/s13011-018-0181-2

${ }^{3}$ Anbarlouei M, Sarbakhsh P, Dadashzadeh H, Ghiasi A, Ataieasl M, Dorosti A, Mohammadpoorasl A. Cigarette and hookah smoking and their relationship with self-esteem and communication skills among high school students. Health Promot Perspect. 2018;8(3):230-236. https://doi.org/10.15171/hpp.2018.31

${ }^{4}$ Khosravi A, Mohammadpoorasl A, Holakouie-Naieni K, Mahmoodi M, Pouyan AA, Mansournia MA. Causal Effect of Self-esteem on Cigarette Smoking Stages in Adolescents: Coarsened Exact Matching in a Longitudinal Study. Osong Public Health Res Perspect. 2016 Dec;7(6):341-345. https://doi.org/10.1016/j.phrp.2016.10.003
} 